\title{
The effect of paracrine/autocrine interactions on the in vitro culture of bovine preimplantation embryos
}

\author{
Nadia Gopichandran ${ }^{1}$ and Henry J Leese \\ Department of Biology (Area 3), University of York, PO Box 373, York YO10 5YW, UK and ${ }^{1}$ Level 4 Institute for \\ Molecular Medicine, Epidemiology and Cancer Research, St James's University Hospital, Beckett Street, Leeds LS9 \\ TTF, UK
}

Correspondence should be addressed to N Gopichandran; Email: n.gopichandran@leeds.ac.uk

\begin{abstract}
Bovine preimplantation embryos develop more successfully when cultured in groups, proibably because of the increased production of, and exposure to, embryotrophic autocrine and paracrine factors. Using a novel embryo culture technique, this study had two aims: 1. to determine the distance over which potential paracrine interactions affect bovine embryo development in terms of blastocyst and hatching rates, cell counts and carbohydrate metabolism; 2. to investigate the effect of platelet-activating factor (PAF) supplementation on bovine embryo development and metabolism. Groups of 16 presumptive zygotes were attached to the bottom of a culture dish by the cell adhesive Cell-Tak in a $4 \times 4$ equidistant array. The distance between individual embryos in each group was 0-689 $\mu \mathrm{m}$. Optimal blastocyst formation rate occurred when embryos were cultured $165 \mu \mathrm{m}$ apart compared with control non-attached zygotes (Kruskal-Wallis followed by Mann-Whitney $U$ test post-hoc; $P<0.05$ ). Increasing the distance between embryos resulted in a further decline in blastocyst rate, which reached zero at $540 \mu \mathrm{m}$ apart. Blastocyst cell number, pyruvate/glucose uptake and lactate production decreased as the interembryo distance increased from 240 to $465 \mu \mathrm{m}(P<0.05)$. Supplementation with PAF during conventional group culture enhanced blastocyst cell number, hatching rates and the oxidative metabolism of pyruvate and glucose. The data indicate that the distance between individual bovine embryos in culture influences preimplantation development, in particular blastocyst formation, cell number and metabolism. It is suggested that diffusible paracrine/autocrine factors, such as PAF, are in part responsible for the regulation of early embryo development.

Reproduction (2006) 131 269-277
\end{abstract}

\section{Introduction}

The preimplantation mammalian embryo is relatively autonomous and can regulate cell division and differentiation without being in contact with the maternal reproductive tract (Schultz \& Heyner 1993). In vivo, it is exposed to numerous factors, absent in vitro, which mediate maternal-embryonic dialogue (Paria \& Dey 1990, Hill 2001) and could partly be responsible for the impaired in vitro development and viability of in vitro cultured preimplantation embryos (Harlow \& Quinn 1982). This manifests as chromosomal abnormalities (Jamieson et al. 1994, Munné et al. 1994), inadequate oocyte nuclear and cytoplasmic maturation (Moor et al. 1998), altered gene expression (Wrenzycki et al. 1998, 2001, Niemann \& Wrenzycki 2000), increased levels of apoptosis (Brison \& Schultz 1997) and metabolic perturbation (Bavister 1995, Gardner \& Lane 1996).

Embryo culture media do not reflect the composition of the fluids found in the maternal tract, which contain a variety of putative mediators such that the embryo may reside in a local 'conditioned' environment (Lane \& Gardner 1992). While a number of studies have attempted to establish the nutrient profile of the female reproductive tract, little is known about the nature and abundance of putative mediators (Orsi et al. 2005). The culture of zygotes individually in large volumes results in inferior development to the blastocyst stage and a reduced cell number compared with those cultured in groups (Paria \& Dey 1990, Lane \& Gardner 1992, O'Neill 1997). O'Neill (1997) suggested that the critical factor in promoting murine zygote development is the number of embryos rather than the volume of the drop. Increasing embryo density also stimulates the rate of compaction (Stoddart et al. 1996), cavitation (Wiley et al. 1986, Paria \& Dey 1990), zona hatching, inner cell mass (ICM) and trophectoderm (TE) cell number (Stoddart et al. 1996), and implantation rate in the mouse (Lane \& Gardner 1992). A similar pattern is seen in the bovine embryo, where group culture increases blastocyst formation, cell number and the 
production of interferon-tau (O'Doherty et al. 1997, Larson \& Kubisch 1999, Khurana \& Niemann 2000).

Growth factor supplementation can compensate for the adverse effects of culture in large volumes and thus enhance embryo development in vitro (Paria \& Dey 1990, O'Neill 1997, 1998), and a number of studies have attempted to identify putative embryo-derived factors that act via paracrine or autocrine pathways. For example, addition of insulin-like growth factor (IGF)-I, IGF-II, platelet activating factor (PAF) (O'Neill 1997) or plateletderived growth factor (PDGF) (Thibodeaux et al. 1993) to bovine and murine embryos cultured in decreasing embryo densities counteracted such dilution effects, ultimately leading to an increase in development. It was suggested that these embryo-derived factors acted as 'survival' factors limiting apoptosis rather than classical growth factors (O'Neill 1991, 1998).

PAF (1-O-alkyl-2-acetyl-sn-glycero-3-phosphocholine) is a low-molecular-weight ether-phospholipid which mediates a wide range of biological functions (reviewed by Hanahan 1986). It is produced by preimplantation embryos in a number of species: man (Collier et al. 1988), sheep (Battye et al. 1991), mouse (O'Neill 1985) and rabbit (Minhas et al. 1993). PAF is also produced by the uterine epithelium and is present in rabbit uterine fluid (Angle et al. 1988). It can act in an autocrine and/or paracrine manner to improve murine embryo development (Stoddart et al. 1996, O’Neil 1997), especially at low embryo culture densities (O'Neill 1998). Supplementation of culture medium with the biologically active C16 isoform of PAF (Stoddart et al. 2001) increases implantation rate (Ryan et al. 1990a), placental mass (Ryan et al. 1990a) and the viability of embryos for uterine transfer $\left(\mathrm{O}^{\prime} \mathrm{Neill}\right.$ et al. 1989). Furthermore, PAF can increase mitosis (Roberts et al. 1993) and reduce apoptosis (O'Neill 1998), blastocyst cell number (Stoddart et al. 1996, O'Neill 1997) and the oxidative metabolism of glucose and lactate (Ryan et al. 1989, 1990b). Despite the clear effects of PAF on the embryos of a number of mammalian species, its potential as an embryotrophic factor for bovine embryos remains to be determined.

In this study, we have examined over what distance potential paracrine interactions affect bovine embryo development in terms of blastocyst and hatching rates, cell counts and metabolism. In order to undertake these experiments, a novel technique was developed to enable embryos to be fixed in a grid layout within a culture drop (Gopichandran 2004). We have also examined the effect of supplementing culture medium with PAF on bovine embryo development and metabolism and assessed its ability to enhance the development of embryos cultured large distances apart.

\section{Materials and Methods}

\section{In vitro production of bovine embryos}

All chemicals were purchased from Sigma unless otherwise stated. In vitro produced (IVP) embryos were derived as previously described (Gopichandran \& Leese 2003). Cumulus-oocyte complexes (COCs) were aspirated from abattoir-derived ovarian follicles $3-10 \mathrm{~mm}$ in diameter into Hepes-buffered tissue culture medium (TCM)-199 supplemented with $50 \mu \mathrm{g} / \mathrm{ml}$ kanamycin monosulphate, $2 \mu \mathrm{g}$ heparin/ml and $1.5 \mathrm{mg} \mathrm{BSA} / \mathrm{ml}$. COCs with an evenly shaded cytoplasm and several layers of granulosa cells were selected and transferred to TCM-199 supplemented with $10 \%$ fetal bovine serum, $0.025 \mathrm{IU}$ follicle-stimulating hormone/luteinising hormone (FSH/LH) (Ferring Pharaceuticals, Langley, UK), $0.47 \mu$ g epidermal growth factor/ml (long EGF) and $10.9 \mathrm{ng}$ fibroblast growth factor/ml (bovine FGF) and incubated for $24 \mathrm{~h}$ at $39^{\circ} \mathrm{C}$ under a humidified atmosphere of $5 \% \mathrm{CO}_{2}$ in air. After maturation, OCCs were washed in Hepes-buffered Tyrode's albumin-lactatepyruvate (Hepes-TALP) and fertilization-TALP (Fert-TALP) (Lu et al. 1987) supplemented with $10 \mu \mathrm{g}$ heparin $/ \mathrm{ml}$, $600 \mu \mathrm{g}$ penicillamine/ml and $220 \mu \mathrm{g}$ hypotaurine/ml.

Spermatozoa were prepared from a frozen-thawed semen sample with discontinuous Percoll (Pharmacia Biotech, St Albans, UK) gradient (45:90) and centrifuged at $2100 \mathrm{~g}$ for $25 \mathrm{~min}$ and $10 \mathrm{~min}$ at $1500 \mathrm{~g}$ after resuspension of the viable sperm pellet in Hepes-TALP. The sperm suspension was adjusted to give a final concentration of $1 \times 10^{6}$ spermatozoa $/ \mathrm{ml}$ and added to each well of a fourwell plate which contained 45-65 oocytes previously washed in Hepes-TALP and Fert-TALP. The plates were incubated at $39^{\circ} \mathrm{C}$ under a humidified atmosphere of $5 \%$ $\mathrm{CO}_{2}$ in air. After $18 \mathrm{~h}$, presumptive zygotes were denuded by vortexing for 2 min in Hepes-buffered synthetic oviductal fluid (SOF) supplemented with minimum essential and non-essential amino acids (Gibco, Life Technologies, Paisley, Scotland), $1 \mathrm{mmol}$ glutamine/l and $4 \mathrm{mg} \mathrm{BSA} / \mathrm{ml}$ (Hepes-SOFaaBSA) (Tervit et al. 1972).

\section{Preparation of Cell-Tak grids}

A working stock of Cell-Tak (VWR International, Leicestershire, UK) was prepared by adding $1 \mathrm{M} \mathrm{NaHCO}_{3}$ to an equal volume of Cell-Tak stock solution $(1.45 \mathrm{mg}$ in $5 \%$ acetic acid $/ \mathrm{ml}$ ). A $1 \mu \mathrm{l}$ drop of working stock was placed in the centre of a dish, spread over a $1 \mathrm{~mm}^{2}$ area, dried and washed according to the manufacturer's instructions. Once treated, the area was covered with $20 \mu \mathrm{I}$ BSAfree SOFaa. This was used in preference to SOFaaBSA, as serum proteins can block the adhesive sites and thus reduce the attachment of the embryo to the surface. Zygotes were randomly pooled into groups of 16 and washed in BSA-free SOFaa. The first embryo was placed on the Cell-Tak grid and the second added a measured distance apart with the aid of an eyepiece graticule, calibrated with a stage micrometer. The remaining embryos 
were placed on the Cell-Tak to form a $4 \times 4$ equidistant grid. The distance between individual zygotes in different dishes was $0-689 \mu \mathrm{m}$ ( $n=12$ for each of the 10 different ranges used) (Fig. 1). The SOFaa surrounding the embryos was removed and replaced with $20 \mu \mathrm{l}$ SOFaaBSA. Control drops containing 16 embryos cultured in the absence of Cell-Tak were placed in separate dishes at the same time. All drops were cultured continuously at $39^{\circ} \mathrm{C}$ in a humidified atmosphere of $5 \% \mathrm{CO}_{2}, 5 \% \mathrm{O}_{2}$ and $90 \% \mathrm{~N}_{2}$. Blastocyst and hatching rates were measured on days 7 and 8 . Although a day- 8 bovine blastocyst has only half the viability of a day-7 one (Hasler et al. 1995), continuing the culture to day 8 enabled hatching rates to be included.

\section{Culture of embryos in PAF}

A $1.909 \mathrm{mmol}$ stock of PAF/I (C16 isoform) (Stoddart et al. 2001) was prepared in ethanol and diluted in SOFaaBSA to give a range of concentrations $(0.5-20 \mu \mathrm{M})$. Controls were also prepared in which the corresponding volumes of ethanol were added to SOFaaBSA $(0.026-1.04 \%(\mathrm{v} / \mathrm{v})$ ethanol). Putative zygotes were cultured in groups of 16 in $20 \mu \mathrm{l}$ culture drops of SOFaaBSA \pm PAF or ethanol as described above ( $n=10$ per concentration). Blastocyst and hatching rates were assessed on days 7 and 8 .

\section{Addition of PAF to bovine embryos incubated at distances over $390 \mu \mathrm{m}$ apart}

Sixteen zygotes were cultured on Cell-Tak in a $4 \times 4$ grid array at distances greater than $390 \mu \mathrm{m}$ apart. This point was selected, as blastocyst rates were significantly lower there than at the optimal distance apart $(165 \mu \mathrm{m})$ or when in direct contact (Fig. 1). Embryos were cultured in SOFaaBSA \pm 10 or $20 \mu \mathrm{M}$ PAF $(n=8$ for each concentration). These concentrations of PAF were selected because previous experiments suggested that they increased embryo development significantly, in terms of hatching rate and blastocyst cell number (Figs 4 and 5). Embryos were cultured as described above.

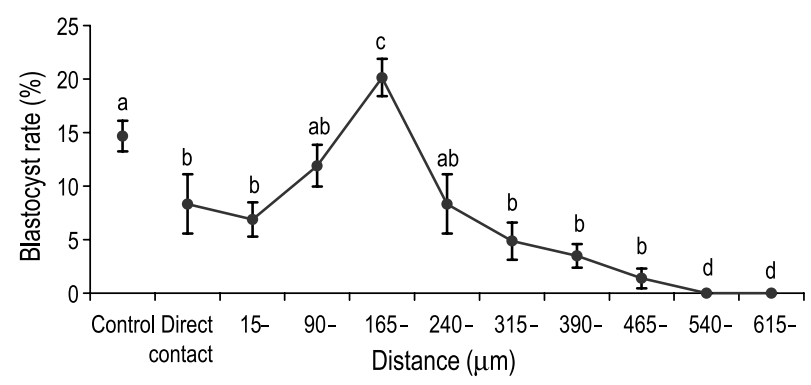

Figure 1 Day-8 blastocyst rate for bovine zygotes cultured at increasing distances apart. Values with different letters are significantly different $(P<0.05)$. Control values are for embryos grown in conventional group culture.

\section{Incubation of blastocysts for carbohydrate profiling} (pyruvate and glucose depletion; lactate appearance)

Single expanding to expanded blastocysts were either gently removed from their position on the Cell-Tak grid $(n=21$ per distance) or removed from culture in the presence of PAF ( $n=12$ per concentration), transferred to $135 \mathrm{nl}$ drops of SOFaaBSA and cultured for $45 \mathrm{~min}$ under a mineral oil overlay in a humidified atmosphere of $5 \%$ $\mathrm{CO}_{2}$ in air at $39^{\circ} \mathrm{C}$. Control droplets were incubated alongside the embryo-containing drops to account for any non-specific loss of nutrients.

\section{Blastocyst cell counts}

After incubation, the zona pellucida was removed from each blastocyst with $0.5 \%$ pronase (Van Soom et al. 2001). Blastocysts were transferred to bisbenzimide dissolved in ethanol $(50 \mu \mathrm{g} / \mathrm{ml})$ for $1 \mathrm{~h}$, washed in $100 \%$ ethanol and mounted singly in $1 \mu \mathrm{l}$ drops of glycerol on siliconised slides. The nuclei in each blastocyst were counted three times under a Vickers microscope.

\section{Ultramicrofluorometric assays}

The concentrations of pyruvate, lactate and glucose in incubation droplets were measured non-invasively by ultramicrofluorometric techniques (Leese \& Barton 1984, Gardner \& Leese 1990). The changes in fluorescence were quantified with a Lecia Fluovert microscope with photomultiplier and photometer attachments.

\section{Statistical analysis}

The normality of all data was assessed by the AndersonDarling test. Cell counts and arcsine-log transformed blastocyst and hatching rates were distributed non-parametrically and were therefore tested by the KruskalWallis test followed by the Mann-Whitney $U$ test post hoc. Significant differences in metabolic profiles (glucose, lactate and pyruvate) were tested by one-way analysis of variance (ANOVA), followed by Fisher's least significant difference (LSD) test post hoc, as the data were normally distributed. All data were presented as means \pm S.E.M. Blastocyst rates were expressed as percentage of putative zygotes cultured, while the consumption or production of glucose, pyruvate and lactate was expressed as pmol/embryo per $h$.

\section{Results}

\section{Effect of culture distance between individual embryos on development and metabolism}

Zygote to blastocyst rates on day 8 were significantly affected by the distance between adjacent embryos (Fig. 1). There was a significant increase in embryo development from direct contact to $165 \mu \mathrm{m}$ apart $(P<0.05)$, at which distance blastocyst rate was maximal. Increases in 
adjacent embryo distance over the range 165-540 $\mu \mathrm{m}$ resulted in a progressive decline in blastocyst rate to zero. The position of each blastocyst within Cell-Tak grids at a distance of $165 \mu \mathrm{m}$ was examined and the number of adjacent embryos recorded (Fig. 2). Embryos with five neighbours appeared to have a higher blastocyst rate than those with three or eight neighbours, although this was significantly higher only between five and eight neighbours. Increasing the distance between individual embryos in culture from direct contact to $165 \mu \mathrm{m}$ increased blastocyst formation but did not significantly affect blastocyst cell number (Figs 1 and 3). At the expanded blastocyst stage, there was a significant fall in cell number as the distance apart was increased from 165 to $240 \mu \mathrm{m}$, although this did not remain significant at higher distances.

Increasing the culture distance between individual bovine embryos significantly affected blastocyst metabolism (Table 1). At distances greater than $165 \mu \mathrm{m}$, there was a trend toward a decrease in glucose and pyruvate uptake, while lactate production was maximal over the range $90-240 \mu \mathrm{m}$ and then decreased $(P<0.05)$. However, when the data were expressed on a per cell basis, any significant differences in blastocyst metabolism were lost.

\section{The effect of PAF on development and metabolism}

Day-7 blastocyst rates were significantly reduced at all concentrations of PAF (Table 2). However, this trend was not seen in day-8 blastocyst rates, where there were no significant differences between controls and PAF-supplemented drops. Day-8 hatching rates were significantly higher in the presence of $10 \mu \mathrm{M}$ PAF, and blastocyst cell number was significantly increased by supplementation with PAF concentrations of $1 \mu \mathrm{M}$ PAF and above (Fig. 4). At the expanded blastocyst stage, cell number was significantly increased at concentrations of PAF above $5 \mu \mathrm{M}$. Culture in the presence of corresponding volumes of ethanol did not affect blastocyst rates (data not shown), indicating that changes in blastocyst and hatching rates were attributable to PAF.

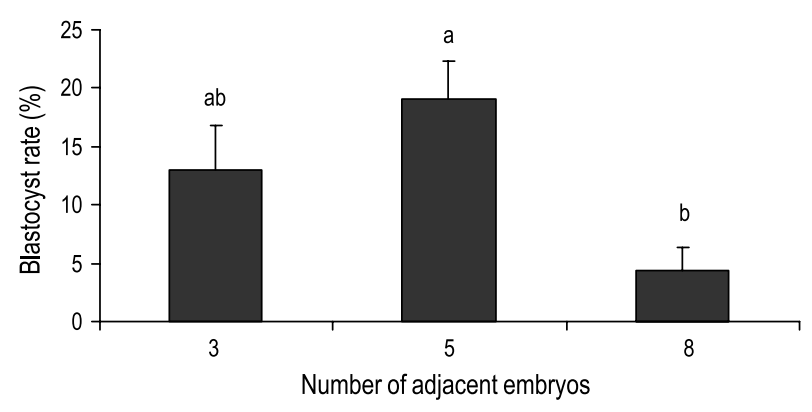

Figure 2 The effect of position in a $4 \times 4$ Cell-Tak grid on subsequent development to the blastocyst stage. Different letters indicate significant differences between distances apart $(P<0.003)$.
The uptakes of pyruvate and glucose by day- 8 blastocysts were significantly increased by $10 \mu \mathrm{M}$ PAF, while no significant differences were seen in lactate production (Table 3). When the results were expressed on a per cell basis, there was a significant increase in pyruvate uptake, but not in glucose uptake and lactate production at concentrations of $\geq 10 \mu \mathrm{M}$ PAF. The culture of embryos at adjacent embryo distances of $\geq 390 \mu \mathrm{m}$ apart in the presence of $10 \mu \mathrm{M}$ PAF significantly increased blastocyst rates compared with controls (Fig. 5). However, in the presence of $20 \mu \mathrm{M}$ PAF, there were no significant differences in blastocyst rates.

\section{Discussion}

Growth factors, either maternal or embryo-derived, have frequently been used as culture medium supplements in an attempt to improve 'suboptimal' rates of embryo development (Paria \& Dey 1990, Morita et al. 1994, O'Neill 1998). Addition of growth factors results in enhanced blastocyst and hatching rates, cell number, metabolic activity and viability. Other strategies have relied on culturing early embryos in small volumes or in groups in order to maximise their exposure to putative embryotrophic factors (Lane \& Gardner 1992, Vajta et al. 2000, Thouas et al. 2003). However, the mechanism(s) by which these agents operate remain(s) unclear. To the best of our knowledge, this is the first study to address the question of the distance over which such putative factors promote embryo development.

\section{The effect of increasing adjacent embryo distance on development of bovine zygotes to the blastocyst stage}

Our data show that both the number of adjacent zygotes and the distance between them influenced development to the blastocyst stage. In particular, there appears to be a distance, $\sim 165 \mu \mathrm{m}$, at which blastocyst formation is highest in vitro. Below this distance, blastocyst rates declined, possibly due to competition for energy substrates such as pyruvate, glucose and amino acids and/or the build-up of metabolic by-products such as ammonium and lactate. Local alterations in physicochemical culture conditions (e.g. oxygen tension, $\mathrm{pH}$, amino-acid profile) and paracrine mediators (e.g. nitric oxide) may also account for this reduction in development. These effects may be particularly important when embryos are in direct contact. By contrast, it seems likely that the presence of these compounds in the immediate surroundings of embryos cultured $\geq 240 \mu \mathrm{m}$ apart would not play such a significant part in influencing embryo development, which seems, instead, to be influenced by a decrease in the availability of putative embryotrophic growth factors.

This proposition is supported by a number of observations. Limitations in pyruvate, glucose and albumin availability have all been shown to affect preimplantation development adversely (Pemble \& Kaye 1986, Chi et al. 


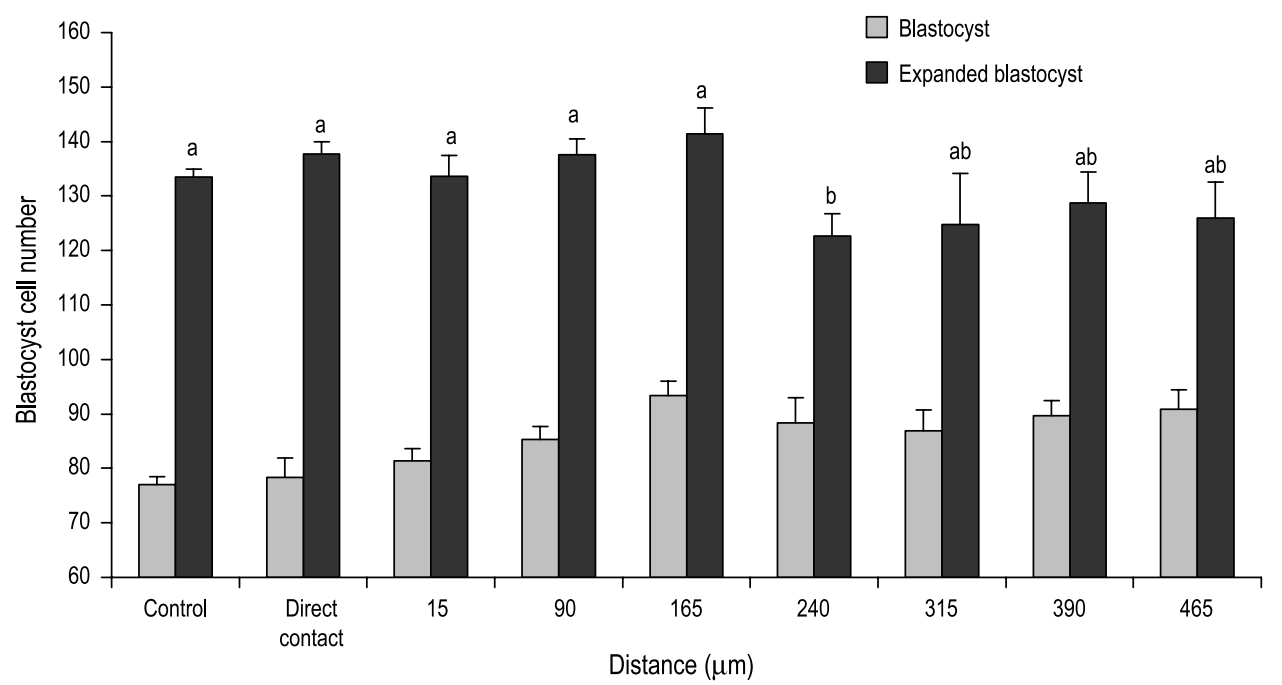

Figure 3 Effect of increasing the distance between individual zygotes on subsequent blastocyst cell number. Different letters indicate significant differences between distances apart $(P<0.05)$.

2002, Orsi \& Leese 2004a). Similarly, ammonium resulting from amino acid breakdown, and lactate derived from glycolysis, can impair development (Lane \& Gardner 1994, Orsi \& Leese 2004b). Exposure of embryos to ammonium can depress oxidative phosphorylation (Lane \& Gardner 2003), decrease blastocyst cell number (Gardner \& Lane 1993) and affect fetal development (Lane \& Gardner 1994, Sinclair et al. 1998). In addition, oxygen tension, $\mathrm{pH}$ and amino-acid profile have all been shown to influence blastocyst rate in a variety of species (Lane \& Bavister 1999, Baltz 2001). Early embryos are vulnerable to oxidative stress (Orsi \& Leese 2001) and have poor homeostatic regulation of acid/base balance until after compaction (Lane 2001).

The number of neighbours influenced the proportion of individual embryos developing to the blastocyst stage at the optimal distance apart, $165 \mu \mathrm{m}$. Intriguingly, better development was obtained when embryos had five neighbours, although this increase was significant only when compared with eight adjacent embryos. The present pattern in blastocyst rates parallels that of other studies in which decreasing embryo density in a specific volume leads to retarded development (Lane \& Gardner 1992, O'Doherty et al. 1997, O'Neill 1997, Khurana \& Niemann 2000). These data suggest that embryo development in vitro is likely to be a cooperative phenomenon (Paria \& Dey 1990, O'Neill 1997). As might be expected, the highest blastocyst cell numbers were recorded at an adjacent embryo distance of $165 \mu \mathrm{m}$; that is, the distance apart at which blastocyst rate was maximal. However, despite their marked effect on blastocyst rate, reducing the distances apart had little effect on the cell count of embryos which reached the blastocyst stage.

\section{The effect of increasing adjacent embryo distance on metabolism}

The carbohydrate metabolism of conventional group cultured bovine blastocysts is consistent with that of other studies (Gopichandran \& Leese 2003). Increasing the distance between the embryos decreased metabolic activity, in terms of in glucose and pyruvate consumption and lactate production. The concentration of embryo-derived

Table 1 The effect of increasing the distance between individual zygotes on carbohydrate metabolism in subsequent day-8 blastocysts. Different superscript letters indicate significant differences between distances apart $(P<0.05)$.

\begin{tabular}{|c|c|c|c|c|c|c|}
\hline \multirow[b]{2}{*}{ Distance between embryos $(\mu \mathrm{m})$} & \multicolumn{3}{|c|}{ Day-8 blastocyst (pmol/embryo/h) } & \multicolumn{3}{|c|}{ Day-8 blastocyst (pmol/cell/h) } \\
\hline & Pyruvate & Glucose & Lactate & Pyruvate & Glucose & Lactate \\
\hline Control & $8.30 \pm 0.93^{\mathrm{a}}$ & $22.48 \pm 1.76^{\mathrm{a}}$ & $39.15 \pm 4.22^{\mathrm{a}}$ & $0.062 \pm 0.007$ & $0.170 \pm 0.014$ & $0.290 \pm 0.013$ \\
\hline 0 & $8.08 \pm 1.21^{\mathrm{a}}$ & $20.15 \pm 2.97^{\mathrm{a}}$ & $27.79 \pm 6.72^{\mathrm{b}}$ & $0.058 \pm 0.008$ & $0.144 \pm 0.020$ & $0.197 \pm 0.021$ \\
\hline 15 & $6.27 \pm 0.93^{\mathrm{ab}}$ & $17.81 \pm 1.55^{\mathrm{ab}}$ & $37.38 \pm 7.83^{\mathrm{ab}}$ & $0.047 \pm 0.007$ & $0.133 \pm 0.011$ & $0.258 \pm 0.010$ \\
\hline 90 & $5.85 \pm 0.94^{b}$ & $20.90 \pm 1.37^{\mathrm{a}}$ & $45.66 \pm 7.45^{\mathrm{a}}$ & $0.042 \pm 0.006$ & $0.151 \pm 0.012$ & $0.319 \pm 0.009$ \\
\hline 165 & $7.37 \pm 0.52^{\mathrm{ab}}$ & $18.23 \pm 1.69^{\mathrm{ab}}$ & $45.14 \pm 7.54^{\mathrm{a}}$ & $0.054 \pm 0.005$ & $0.133 \pm 0.013$ & $0.309 \pm 0.011$ \\
\hline 240 & $4.52 \pm 0.84^{\mathrm{c}}$ & $15.94 \pm 2.30^{\mathrm{b}}$ & $48.13 \pm 7.99^{\mathrm{a}}$ & $0.036 \pm 0.006$ & $0.139 \pm 0.024$ & $0.404 \pm 0.019$ \\
\hline 315 & $5.15 \pm 0.78^{b c}$ & $15.92 \pm 0.74^{\mathrm{b}}$ & $39.55 \pm 3.59^{\mathrm{a}}$ & $0.041 \pm 0.004$ & $0.130 \pm 0.014$ & $0.376 \pm 0.007$ \\
\hline 390 & $4.05 \pm 0.33^{\mathrm{c}}$ & $15.40 \pm 0.50^{\mathrm{b}}$ & $29.37 \pm 5.60^{b}$ & $0.031 \pm 0.002$ & $0.120 \pm 0.004$ & $0.234 \pm 0.003$ \\
\hline 465 & $3.50 \pm 0.89^{c}$ & $14.55 \pm 1.57^{\mathrm{b}}$ & $31.23 \pm 2.32^{\mathrm{b}}$ & $0.027 \pm 0.007$ & $0.116 \pm 0.013$ & $0.272 \pm 0.013$ \\
\hline
\end{tabular}


Table 2 Effect of increasing concentrations of PAF on development of bovine zygotes to the blastocyst stage (days 7 and 8) in conventional group culture. Different superscript letters indicate significant differences between concentrations of PAF $(P<0.001)$.

\begin{tabular}{lccr}
\hline & \multicolumn{3}{c}{ Blastocyst rate $(\%)$} \\
\cline { 2 - 4 } $\begin{array}{l}\text { PAF concentration } \\
(\mu \mathrm{M})\end{array}$ & Day 7 & Day 8 & Day 8 (hatched) \\
\hline 0 & $17.8 \pm 3.64^{\mathrm{a}}$ & $27.8 \pm 4.65$ & $4.4 \pm 1.76^{\mathrm{a}}$ \\
0.5 & $5.6 \pm 1.76^{\mathrm{b}}$ & $23.3 \pm 4.41$ & $4.4 \pm 1.76^{\mathrm{a}}$ \\
1.0 & $5.6 \pm 1.76^{\mathrm{b}}$ & $23.3 \pm 4.71$ & $7.8 \pm 1.47^{\mathrm{a}}$ \\
5.0 & $6.7 \pm 1.67^{\mathrm{b}}$ & $18.9 \pm 2.61$ & $5.6 \pm 1.76^{\mathrm{a}}$ \\
10.0 & $7.8 \pm 2.78^{\mathrm{b}}$ & $21.1 \pm 4.55$ & $16.7 \pm 4.08^{\mathrm{b}}$ \\
20.0 & $0.0 \pm 0.0^{\mathrm{b}}$ & $21.1 \pm 3.51$ & $2.2 \pm 1.47^{\mathrm{a}}$ \\
\hline
\end{tabular}

growth factors may decrease over increasing distances, resulting in a concomitant depression in metabolic activity. For example, exogenous PAF and embryo-derived PAF - in addition to their effects in reducing cell death (O'Neill 1998) and increasing mitosis (Roberts et al. 1993) and blastocyst cell number (Stoddart et al. 1996, O'Neill 1997) - increase the oxidative metabolism of glucose and lactate in the mouse (Ryan et al. 1989, 1990b). Expressing metabolism on a per cell basis revealed no significant effect of adjacent embryo distance. Thus, the decrease in metabolism noted with increasing distance was most likely a consequence of decreased cell number.

These findings highlight the potential applications of this novel culture technique we developed in supporting the development of small numbers of embryos, such as those encountered during routine ovum pick-up cycles. However, we would caution against the use of this technique to culture human embryos conceived by IVF until any potential effects of the constituents of Cell-Tak have been rigorously assessed.

\section{The effect of PAF on development and metabolism}

Exposure of early cattle embryos to PAF led to a significant depression in blastocyst rate on day 7, suggesting an adverse effect on preimplantation development, in contradiction to the report that exogenous PAF increases murine embryo development in a concentration-dependent manner (Stoddart et al. 2001). However, the depression in cavitation rate in the bovine embryo may occur as a result of prolonged compaction (Van Soom et al. 1997). The duration of this morphogenetic event, which is abnormally abbreviated in bovine embryos in vitro, may have increased as a result of exposure to PAF. This is supported by the following observations: 1 . day- 8 blastocyst rates were comparable across groups; 2 . hatching rate was enhanced by $10 \mu \mathrm{M}$ PAF; 3. blastocyst cell numbers were also increased (see below). PAF-free controls containing equivalent volumes of ethanol $(0.026-1.04 \%(\mathrm{v} / \mathrm{v})) \mathrm{did}$ not affect blastocyst rates on days 7 and 8 , confirming that the enhanced rates were due to PAF alone, and not the presence of ethanol. It has been proposed that increasing embryo density and PAF concentration, or reducing culture volume, promotes hatching of mouse blastocysts (Stoddart et al. 1996, Teruel \& Smith 1997, Thouas et al. 2003). This could be the result of an accumulation of the secretory proteolytic enzymes that mediate zona thinning (e.g. strypsin), which may act in a paracrine manner on neighbouring embryos (Perona \& Wassarman 1986, Lee et al. 1997, Mishra \& Seshagiri 1998). It is tempting to speculate that the increase in hatching associated with PAF supplementation results from such enhanced enzyme production.

An increase in blastocyst and expanded blastocyst cell number was seen at PAF concentrations above 1 and $5 \mu \mathrm{M}$ respectively, with no further increases in cell number seen at the higher concentrations of PAF. This agrees with the finding of Roudebush et al. (1996) that high

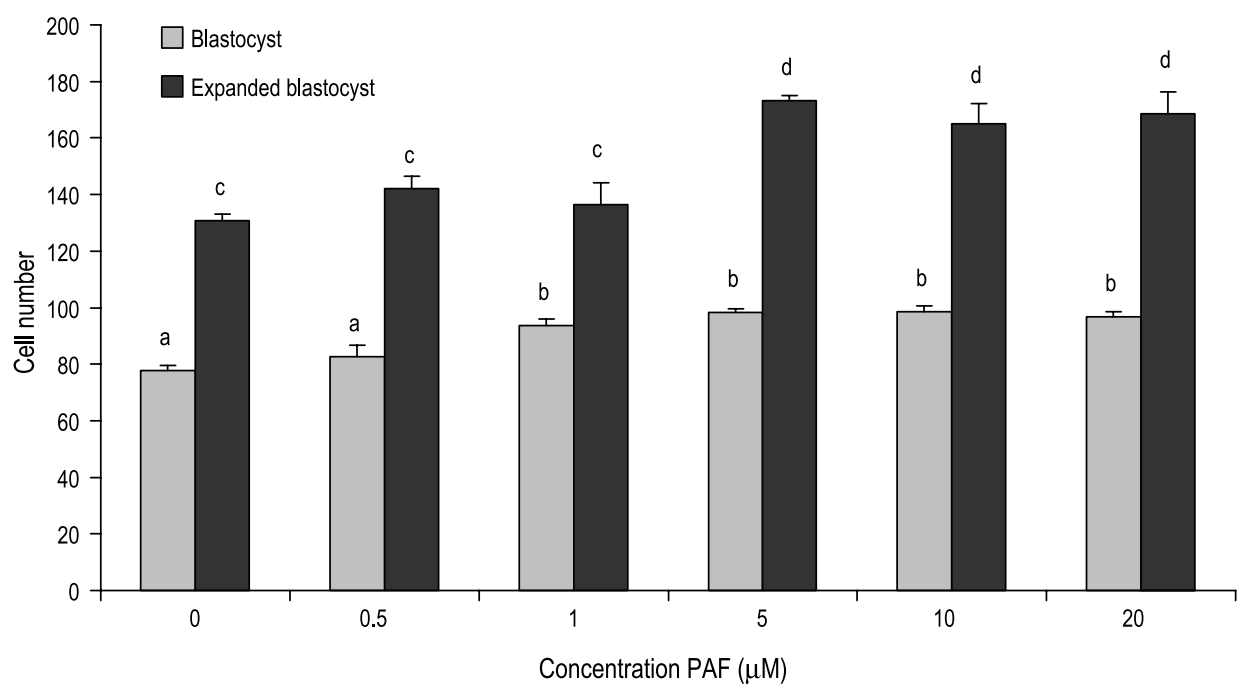

Figure 4 Effect of increasing the concentrations of PAF on development of bovine zygotes to the blastocyst and expanded blastocyst stages in conventional group culture $(P<0.001)$. Different letters indicate significant differences. 
Table 3 Glucose and pyruvate consumption and lactate production by day- 8 blastocysts cultured in conventional groups from the zygote stage in medium supplemented with PAF (glucose $P<0.05$; pyruvate $P<0.001$ ). Different superscript letters indicate significant differences between PAF concentrations. *Conversion of glucose to lactate.

\begin{tabular}{|c|c|c|c|c|c|c|c|c|}
\hline \multirow[b]{2}{*}{$\begin{array}{l}\text { PAF } \\
(\mu \mathrm{M})\end{array}$} & \multicolumn{4}{|c|}{ Day-8 blastocysts (pmol/embryo/h) } & \multicolumn{4}{|c|}{ Day-8 blastocysts (pmol/cell/h) } \\
\hline & Pyruvate & Glucose & Lactate & $\begin{array}{l}\text { Glycolytic index } \\
(\%)^{*}\end{array}$ & Pyruvate & Glucose & Lactate & $\begin{array}{c}\text { Glycolytic index } \\
(\%) *\end{array}$ \\
\hline 0 & $9.86 \pm 1.46^{\mathrm{a}}$ & $21.00 \pm 2.78^{\mathrm{a}}$ & $42.00 \pm 6.70$ & $100.0 \pm 8.2^{\mathrm{a}}$ & $0.126 \pm 0.018^{\mathrm{a}}$ & $0.270 \pm 0.049$ & $0.541 \pm 0.088$ & $98.8 \pm 11.1^{\mathrm{a}}$ \\
\hline 0.5 & $10.32 \pm 1.42^{\mathrm{a}}$ & $20.99 \pm 1.36^{\mathrm{a}}$ & $41.63 \pm 5.77$ & $104.1 \pm 7.0^{\mathrm{a}}$ & $0.124 \pm 0.015^{\mathrm{a}}$ & $0.254 \pm 0.015$ & $0.492 \pm 0.055$ & $103.2 \pm 5.4^{\mathrm{a}}$ \\
\hline 1 & $12.48 \pm 1.25^{\mathrm{a}}$ & $19.82 \pm 2.11^{\mathrm{a}}$ & $41.63 \pm 5.77$ & $95.2 \pm 7.3^{\mathrm{a}}$ & $0.134 \pm 0.012^{\mathrm{a}}$ & $0.214 \pm 0.024$ & $0.449 \pm 0.064$ & $95.3 \pm 7.5^{\mathrm{a}}$ \\
\hline 5 & $13.25 \pm 1.21^{\mathrm{a}}$ & $24.42 \pm 1.43^{\mathrm{a}}$ & $40.50 \pm 2.87$ & $120.5 \pm 9.9^{b}$ & $0.135 \pm 0.012^{\mathrm{a}}$ & $0.249 \pm 0.013$ & $0.413 \pm 0.027$ & $120.5 \pm 9.6^{b}$ \\
\hline 10 & $18.03 \pm 1.90^{b}$ & $28.69 \pm 2.02^{b}$ & $44.72 \pm 2.92$ & $128.3 \pm 13.8^{\mathrm{b}}$ & $0.185 \pm 0.018^{\mathrm{ab}}$ & $0.294 \pm 0.023$ & $0.458 \pm 0.027$ & $128.3 \pm 17.0^{b}$ \\
\hline 20 & $20.72 \pm 1.71^{b}$ & $29.05 \pm 2.34^{\mathrm{b}}$ & $46.43 \pm 3.54$ & $125.1 \pm 13.2^{\mathrm{b}}$ & $0.213 \pm 0.019^{b}$ & $0.299 \pm 0.026$ & $0.476 \pm 0.037$ & $125.6 \pm 14.0^{b}$ \\
\hline
\end{tabular}

concentrations of PAF do not enhance murine embryo development. It is possible that this is a consequence of PAF receptor expression; Roudebush et al. (2002) found a decrease in murine receptor expression during preimplantation development, suggesting that elevated PAF concentrations are likely to saturate functional receptors. In addition, Stojanov and O'Neill (1999) reported a reduction in PAF-receptor mRNA expression after IVF, and suggested that this would lead to a deficiency of this particular autocrine signal, thereby accounting for the limited benefits of exogenous PAF supplementation.

Continuous culture of bovine embryos throughout preimplantation development in the presence of SOFaaBSA supplemented with 10-20 $\mu \mathrm{M}$ PAF led to a significant increase in the utilisation of pyruvate and glucose but did not alter lactate production. These observations suggest an
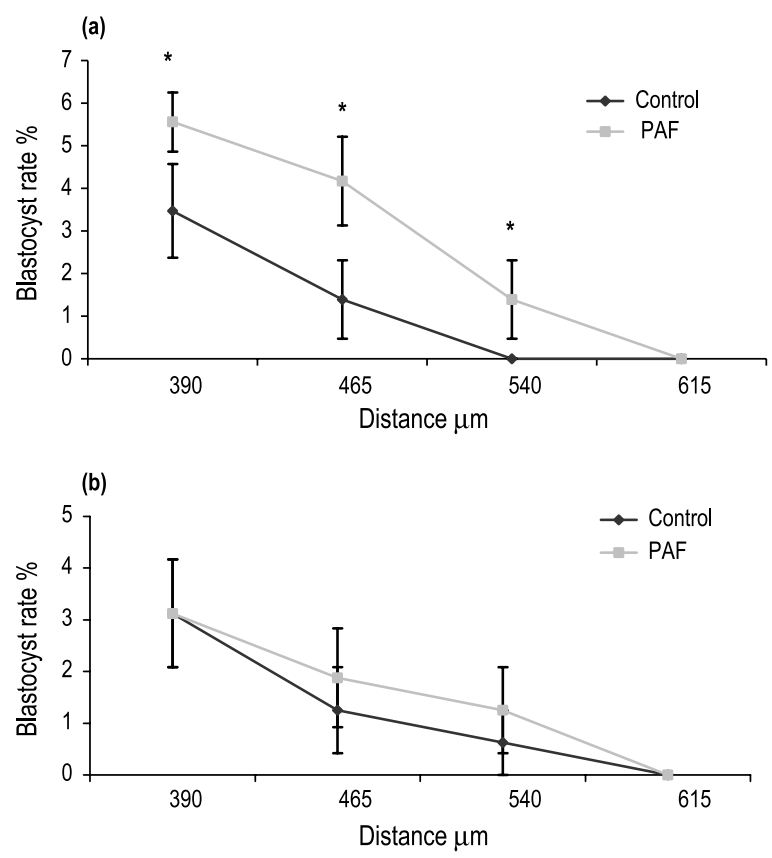

Figure 5 Effect of (a) $10 \mu \mathrm{M}$ and (b) $20 \mu \mathrm{M}$ on the development of individual zygotes cultured to the blastocyst stage at varying distances apart. *Significant differences between controls $(P<0.001)$. enhancement in oxidative metabolism, as reported by Ryan et al. (1989, 1990b), who found a similar dosedependent enhancement of oxidative metabolism by murine blastocysts cultured in the presence of PAF, suggesting that PAF may induce the embryo to favour more energyefficient pathways. Furthermore, the data suggest that $10 \mu \mathrm{M}$ PAF can, to some extent, 'rescue' embryos cultured $\geq 390 \mu \mathrm{m}$ apart. The increase in developmental potential observed in the presence of PAF may occur by increasing embryotrophic factor secretion, the cumulative concentrations of which were insufficient to enhance embryo development.

In conclusion, we have shown that varying the distance between individual bovine zygotes in culture influences their development, in terms of blastocyst formation, cell number and metabolism. Embryo development is optimal at a distance $165 \mu \mathrm{m}$ apart, strongly suggesting a role for diffusible paracrine/autocrine factors. Moreover, it has been suggested that the 'helper' effect in embryo culture, notably in the mouse, whereby one embryo seems to help another, is a function of their 'preferred' growth environment as a polytocous species. The demonstration that similar relationships occur in the normally monotocous cow provides evidence of a more pervasive role for the autocrine stimulation of bovine embryo development.

\section{Acknowledgements}

We thank ABP (York) for the donation of bovine ovaries, Dr N M Orsi for critical review of the manuscript and an anonymous referee for drawing attention to the more pervasive role of autocrine stimulation in the early mammalian embryo. This work was funded by a James Burgess studentship awarded to the University of York.

\section{References}

Angle MJ, Jones MA, McManus LM, Pinckard RN \& Harper MJK 1988 Platelet-activating factor in the rabbit uterus during early pregnancy. Journal of Reproduction and Fertility 83 711-722.

Baltz JM 2001 Osmoregulation and cell volume regulation in the preimplantation embryo. Current Topics in Developmental Biology $5255-106$. 
Battye KM, Ammit AJ, O'Neill C \& Evans G 1991 Production of platelet-activating factor by the pre-implantation sheep embryo. Journal of Reproduction and Fertility 93 507-514.

Bavister BD 1995 Culture of preimplantation embryos: facts and artefacts. Human Reproduction Update 1 91-148.

Brison DR \& Schultz RM 1997 Apoptosis during mouse blastocyst formation: evidence for a role for survival factors including transforming growth factor $\alpha$. Biology of Reproduction 56 1088-1096.

Chi MM-Y, Hoehn A \& Moley KH 2002 Metabolic changes in the glucose-induced apoptotic blastocyst suggest alterations in mitochondrial physiology. American Journal of Physiology. Endocrinology and Metabolism 283 E226-E232.

Collier M, O'Neill C, Ammit AJ \& Saunders DM 1988 Biochemical and pharmacological characterization of human embryo-derived platelet activating factor. Human Reproduction 3 993-998.

Gardner DK \& Lane M 1993 Amino acids and ammonium regulate mouse embryo development in culture. Biology of Reproduction 48 377-385.

Gardner DK \& Lane M 1996 Alleviation of the '2-cell block' and development to the blastocyst of CF1 mouse embryos: role of amino acids, EDTA and physical parameters. Human Reproduction $112703-2712$.

Gardner DK \& Leese HJ 1990 Concentrations of nutrients in mouse oviduct fluid and their effects on embryo development and metabolism in vitro. Journal of Reproduction and Fertility 88 361-368.

Gopichandran N 2004 The development and metabolism of the bovine preimplantation embryo. PhD thesis, University of York.

Gopichandran N \& Leese HJ 2003 Metabolic characterization of the bovine blastocyst, inner cell mass, trophectoderm and blastocoel fluid. Reproduction 126 299-308.

Hanahan DJ 1986 Platelet activating factor: a biologically active phosphoglyceride. Annual Review of Biochemistry 55 483-509.

Harlow GM \& Quinn P 1982 Development of preimplantation mouse embryos in vivo and in vitro. Australian Journal of Biological Sciences 35 187-193.

Hasler JF, Henderson WB, Hurtgen PJ, Jin ZQ, McCauley AD, Mower SA, Neely B, Shuey LS, Stokes JE \& Trimmer SA 1995 Production, freezing and transfer of bovine IVF embryos and subsequent calving results. Theriogenology 43 141-152.

Hill JA 2001 Maternal-embryonic cross-talk. Annals of the New York Academy of Sciences 943 17-25.

Jamieson ME, Coutts JR \& Connor JM 1994 The chromosome constitution of human preimplantation embryos fertilized in vitro. Human Reproduction 9 709-715.

Khurana NK \& Niemann H 2000 Effects of oocyte quality, oxygen tension, embryo density, cumulus cells and energy substrates on cleavage and morula/blastocyst formation of bovine embryos. Theriogenology 15 741-756.

Lane M 2001 Mechanisms for managing cellular and homeostatic stress in vitro. Theriogeneology 55 225-236.

Lane M \& Bavister BD 1999 Regulation of intracellular pH in bovine oocytes and cleavage stage embryos. Molecular Reproduction and Development 54 396-401.

Lane M \& Gardner DK 1992 Effect of incubation volume and embryo density on the development and viability of mouse embryos in vitro. Human Reproduction 7 558-562.

Lane M \& Gardner DK 1994 Increase in postimplantation development of cultured mouse embryos by amino acids and induction of fetal retardation and exencephaly by ammonium ions. Journal of Reproduction and Fertility 102 305-312.

Lane M \& Gardner DK 2003 Ammonium induces aberrant blastocyst differentiation, metabolism, $\mathrm{pH}$ regulation, gene expression and subsequently alters fetal development in the mouse. Biology of Reproduction 69 1109-1117.

Larson MA \& Kubisch HM 1999 The effects of group size on development and interferon- $\tau$ secretion by in vitro fertilized and cultured bovine blastocysts. Human Reproduction 14 2075-2079.
Lee DR, Lee JE, Yoon HS, Lee HJ, Kim MK \& Roh SI 1997 The supplementation of culture medium with protease improves the hatching rate of mouse embryos. Human Reproduction 12 2493-2498.

Leese HJ \& Barton AM 1984 Pyruvate and glucose uptake by mouse ova and preimplantation embryos. Journal of Reproduction and Fertility 72 9-13.

Minhas BS, Zhu YP, Kim HN, Burwinkel TH, Ripps BA \& Buste JE 1993 Embryonic platelet activating factor production in the rabbit increases during the preimplantation phase. Journal of Assisted Reproduction and Genetics 10 366-370.

Mishra A \& Seshagiri PB 1998 Successful development in vitro of hamster 8-cell embryos to 'zona-escaped' and attached blastocysts: assessment of quality and trophoblast outgrowth. Reproduction Fertility and Development 10 413-420.

Moor RM, Dai Y, Lee C \& Fulka J Jr 1998 Oocyte maturation and embryonic failure. Human Reproduction Update 4 223-236.

Morita Y, Tsutsumi O \& Taketani Y 1994 In vitro treatment of embryos with epidermal growth factor improves viability and increases the implantation rate of blastocysts transferred to recipient mice. American Journal of Obstetrics and Gynecology 171 406-409.

Munné S, Grifo J, Cohen J \& Weier HU 1994 Chromosome abnormalities in human arrested preimplantation embryos: a multipleprobe FISH study. American Journal of Human Genetics $\mathbf{5 5}$ $150-159$.

Niemann H \& Wrenzycki C 2000 Alterations of expression of developmentally important genes in preimplantation bovine embryos by in vitro culture conditions: implications for subsequent development. Theriogenology 53 21-34.

O'Doherty EM, Wade MG, Hill JL \& Boland MP 1997 Effects of culturing bovine oocytes either singly or in groups on development to blastocysts. Theriogenology 48 161-169.

O'Neill C 1985 Partial characterization of the embryo-derived plateletactivating factor in mice. Journal of Reproduction and Fertility $\mathbf{7 5}$ $375-380$.

O'Neill C 1991 A physiological role for PAF in the stimulation of mammalian embryonic development. Trends in Biochemical Sciences 12 82-84.

O'Neill C 1997 Evidence for the requirement of autocrine growth factors for development of mouse preimplantation embryos in vitro. Biology of Reproduction 56 229-237.

O'Neill C 1998 Role of autocrine mediators in the regulation of embryo viability: lessons from animal models. Journal of Assisted Reproduction and Genetics 15 460-465.

O'Neill C, Ryan JP, Collier M, Saunders DM, Ammit AJ, \& Pike IL 1989 Supplementation of in-vitro fertilisation culture medium with platelet activating factor. Lancet 2 769-772.

Orsi NM, Gopichandran N, Leese HJ, Picton HM \& Harris SE 2005 Fluctuations in bovine ovarian follicular fluid composition throughout the oestrous cycle: a comparison with plasma and a TCM-199-based maturation medium. Reproduction 129 219-228.

Orsi NM \& Leese HJ 2004a Ammonium exposure and pyruvate affect the amino acid metabolism of bovine blastocysts in vitro. Reproduction 127 131-140.

Orsi NM \& Leese HJ 2004b Amino acid metabolism of preimplantation bovine embryos cultured with bovine serum albumin or polyvinyl alcohol. Theriogenology 15 561-572.

Orsi NM \& Leese HJ 2001 Protection against reactive oxygen species during mouse preimplantation embryo development: role of EDTA, oxygen tension, catalase, superoxide dismutase and pyruvate. Molecular Reproduction and Development 59 44-53.

Paria BC \& Dey SK 1990 Preimplantation embryo development in vitro: cooperative interactions among embryos and role of growth factors. PNAS 87 4756-4760.

Pemble LB \& Kaye PL 1986 Whole protein uptake and metabolism by mouse blastocysts. Journal of Reproduction and Fertility $\mathbf{7 8}$ 149-157. 
Perona RM \& Wassarman PM 1986 Mouse blastocysts hatch in vitro by using a trypsin-like proteinase associated with cells of mural trophectoderm. Developmental Biology 114 42-52.

Roberts C, O'Neill C \& Wright L 1993 Platelet activating factor (PAF) enhances mitosis in preimplantation mouse embryos. Reproduction, Fertility, and Development 5 271-279.

Roudebush WE, Duralia DR \& Butler WJ 1996 Effect of plateletactivating factor (PAF) on preimplantation mouse B6D2F1/J embryo formation. American Journal of Reproductive Immunology 35 272-276.

Roudebush WE, Purnell ET, Stoddart NR \& Fleming SD 2002 Embryonic platelet-activating factor: temporal expression of the ligand and receptor. Journal of Assisted Reproduction and Genetics $1972-78$.

Ryan JP, Spinks NR, O'Neill C, Ammit AJ \& Wales RG 1989 Platelet activating factor (PAF) production by mouse in vitro and its effect on embryonic metabolism. Journal of Cellular Biochemistry $\mathbf{4 0}$ 387-395.

Ryan JP, Spinks NR, O'Neill C \& Wales RG 1990a Implantation potential and fetal viability of mouse embryos cultured in media supplemented with platelet-activating factor. Journal of Reproduction and Fertility 89 309-315.

Ryan JP, O'Neill C \& Wales PG 1990b Oxidative metabolism of energy substrates by preimplantation mouse embryos in the presence of platelet-activating factor. Journal of Reproduction and Fertility $89301-307$.

Schultz GA \& Heyner S 1993 Growth factors in preimplantation mammalian embryos. Oxford Reviews in Reproductive Biology 15 $43-81$.

Sinclair KD, Dunne LD, Maxfield EK, Maltin CA, Young LE, Wilmut I, Robinson JJ \& Broadbent PJ 1998 Fetal growth and development following temporary exposure of day 3 ovine embryos to an advanced uterine environment. Reproduction, Fertility, and Development $10263-269$.

Stoddart NR, Wild AE \& Fleming TP 1996 Stimulation of development in vitro by platelet-activating factor receptor ligands released by mouse preimplantation embryos. Journal of Reproduction and Fertility 108 47-53.

Stoddart NR, Roudebush W \& Fleming SD 2001 Exogenous plateletactivating factor stimulates cell proliferation in mouse preimplantation embryos prior to the fourth cell cycle and shows isoform-specific stimulatory effects. Zygote 9 261-268.

Stojanov T \& O'Neill C 1999 Ontogney of expression of a receptor for platelet-activating factor in mouse preimplantation embryos and the effects of fertilisation and culture in vitro on its expression. Biology of Reproduction 60 674-682.
Teruel M \& Smith R 1997 Effect of embryo density and growth factors on in vitro preimplantation development of mouse embryos. Acta physiologica, pharmacologica et therapeutica latinoamericana 47 87-96.

Tervit HR, Whittingham DG \& Rowson LE 1972 Successful culture in vitro of sheep and cattle ova. Journal of Reproduction and Fertility $30493-497$.

Thibodeaux JK, Del Vecchio RP \& Hansel W 1993 Role of plateletderived growth factor in development of in vitro matured and in vitro fertilized bovine embroys. Journal of Reproduction and Fertility 98 61-66.

Thouas GA, Jones GM \& Trounson AO 2003 The 'GO' system - a novel method of microculture for in vitro development of mouse zygotes to the blastocyst stage. Reproduction 126 161-169.

Vajta G, Peura TT, Holm P, Páldi A, Greve T, Trounson AO \& Callesen H 2000 New method for culture of zona-included or zona-free embryos: the well of the well (WOW) system. Molecular Reproduction and Development 55 256-264.

Van Soom A, Boerjan ML, Bols PEJ, Vanroose G, Lein A, Coryn M \& de Kruif A 1997 Timing of compaction and inner cell allocation in bovine embryos produced in vivo after superovulation. Biology of Reproduction 57 1041-1049.

Van Soom A, Vanroose G \& de Kruif A 2001 Blastocyst evaluation by means of differential staining: a practical approach. Reproduction in Domestic Animals 36 29-35.

Wiley LM, Yamami S \& Van Muyden D 1986 Effect of potassium concentration, type of protein supplement, and embryo density on mouse preimplantation development in vitro. Fertility and Sterility $45111-119$.

Wrenzycki C, Herrmann D, Carnwath JW \& Niemann H 1998 Expression of RNA from developmentally important genes in preimplantation bovine embryos produced in TCM supplemented with BSA. Journal of Reproduction and Fertility 112 387-398.

Wrenzycki C, Herrmann D, Keskintepe L, Martins A Jr, Sirisathien S, Brackett B \& Niemann H 2001 Effects of culture system and protein supplementation on mRNA expression in preimplantation bovine embryos. Human Reproduction 16 893-901.

Received 2 February 2005

First decision 29 March 2005

Revised manuscript received 12 September 2005

Accepted 11 October 2005 